\title{
ОЦІНКА ЯКОСТІ ГІДРОФОБІЗУЮЧИХ ДОБАВОК І ЇХ ВПЛИВ НА ВОДОСТІЙКІСТЬ ГІІІУ
}

Кандидати техн. наук А.В. Фощ, В.Я. Керш, старш. викл. А.В. Колесніков

\section{ОЦЕНКА КАЧЕСТВА ГИДРОФОБИЗИРУЮЩИХ ДОБАВОК И ИХ ВЛИЯНИЕ НА ВОДОСТОЙКОСТЬ ГИПСА.}

\author{
Кандидаты техн. наук А.В. Фош, В.Я. Керш, старш. преп. А.В. Колесников

\section{THE INFLUENCE OF MICROSILICA AND MECHANOACTIVATION ON EFFECTIVE VISCOSITY OF CEMENT SUSPENSIONS}

\author{
Cand. of techn. sciences A. Foshch, V. Kersh, assistant professor A. Kolesnikov
}

У статті розглядаються питання оцінки якості гідрофобізуючих добавок по крайовому куту змочування та їх впливу на водостійкість гіпсу. Проведений експеримент дозволив вибрати найбільш ефективну гідрофобізуючу добавку серед обраних, встановити оптимальну ї̈ концентрацію та спосіб застосування. Виявлено, що гідрофобізатор ГКЖ-11К підвищує коефіцієнт розм'якшення гіпсу на 33 \% при концентрачії добавки $1 \%$ маси в'яжучого.

Ключові слова: гіпс, водостійкість, гідрофобізуюча добавка, крайовий кут змочування, коефіцієнт розм'якшення.

В статье рассматриваются вопросы оченки качества гидрофобизирующих добавок по краевому углу смачивания и их влияние на водостойкость гипса. Проведенный эксперимент позволил выбрать наиболее эффективную гидрофобизирующую добавку среди выбранных, установить оптимальную её конщентраџию и способ применения. Выявлено, что гидрофобизатор ГКЖ-11К повышает коэффициент размягчения гипса на 33 \% при конщентрации добавки 1 \% массы вяжущего.

Ключевые слова: гипс, водостойкость, гидрофобизирующая добавка, краевой угол смачивания, коэффициент размягчения.

The paper deals with the evaluation of the quality waterproofing additives for contact angle of wetting and their impact on the water resistance of gypsum. The experiment allowed to choose the most effective repellent additive among the candidates, it set the optimal concentration and method of application. It was revealed that the water repellent GKZ- $11 \mathrm{~K}$ increases the rate of softening of gypsum is $33 \%$ at a concentration of additive $1 \%$ by weight of the binder.

Keywords: gypsum, water-resistance, waterproofing additive, the contact angle, the ratio of softening.

Вступ. Виробництво ефективних будівельних матеріалів і виробів, що відповідають сучасним вимогам 3 екологічності, основних фізико-механічних характеристик, доступності і вартості, - важливе і не вирішене в повному обсязі завдання будівництва і промисловості будівельних матеріалів.

Будівельні матеріали на основі гіпсової сировини відрізняються низькими енергозатратами при виробництві та кращими екологічними показниками порівняно 3 цементними матеріалами аналогічного призначення [1].

Постановка проблеми в загальному вигляді та її зв'язок з важливими науковими i практичними завданнями. Вітчизняний i зарубіжний досвід застосування гіпсових матеріалів у будівництві та результати науководослідних розробок у цій галузі показують [2], що застосування гіпсових матеріалів абсолютно недостатньо. Перегородки 3 гіпсокартонних листів (ГКЛ) i в деяких випадках 3 пазогребеневих плит, підвісні стелі, ряд оздоблювальних матеріалів у приміщеннях 3 відносною вологістю повітря до $60 \%$ - на сьогодні найбільш відомі варіанти застосування гіпсових виробів. Значно менше гіпсові матеріали застосовуються в шпаклівках, клеях, штукатурних розчинах. I зовсім мало в якості 
теплоізоляційних ніздрюватих бетонів: піногіпс, газогіпс, полістиролгіпсобетон [3, 4].

Основною причиною обмеження сфери їх використання $є$ низька водостійкість гіпсового каменю, що призводить до втрати міцності гіпсових виробів у вологих умовах. Тому підвищення водостійкості гіпсу $є$ актуальним завданням.

Аналіз останніх досліджень і публікацій. Дослідження, проведені протягом останніх десятиліть, дозволили виявити найбільш ефективні шляхи підвищення водостійкості матеріалів на основі гіпсового в'яжучого [5-10]:

- підвищення щільності виробів за рахунок їх виготовлення методом трамбування та вібропресування з малопластичних сумішей;

- застосування хімічних добавок, у тому числі пластифікуючих, що дозволяють модифікувати різні властивості гіпсу;

- зменшення розчинності у воді сульфату кальцію і створення умов утворення нерозчинних сполук, що захищають дигідрат сульфату кальцію, поєднанням гіпсових в'яжучих 3 гідравлічними компонентами (вапном, портландцементом, активними мінеральними добавками). У якості пуцоланової добавки зазвичай використовують трепел, діатоміт, опоки, активні золи, гранульовані доменні шлаки та ін.;

- підвищення водостійкості гіпсових виробів зовнішньою та об'ємною гідрофобізацією.

Застосування гідрофобізаторів активно розвивається за кордоном і отримало широке застосування при виробництві сучасних водостійких матеріалів на основі гіпсу (штукатурки, шпаклівки, гіпсокартонні плити та ін.). У якості речовин, що забезпечують захист гіпсового каменю від дії води, використовують різні емульсії, у складі яких присутні полівініловий спирт, стеаринова кислота, парафін, алкілфенол, крохмаль, аміноальдегідні смоли, алкілоксисилани та ін. [11].

Визначення мети та задач досліджень. Метою дослідження є підвищення водостійкості гіпсу за допомогою використання гідрофобізуючих добавок.

Завдання досліджень - оцінити якість вітчизняних і зарубіжних гідрофобізуючих добавок і дослідити їх вплив на водостійкість гіпсу.

Основна частина досліджень. Вплив вітчизняних i зарубіжних гідрофобізуючих добавок на водостійкість гіпсу визначали за крайовим кутом змочування поверхні матеріалу за допомогою програми AmCap i визначенням коефіцієнта розм'якшення гіпсобетону. Дослідження проводилися на в'яжучому марки Г-5-Б-ІІ виробництва ВАТ «Івано-Франківськцемент» і високоміцний гіпс марки Г-10-Б-ІІІ виробництва ТОВ «Кнауф ГІПС Донбас».

Оскільки одним із важливих факторів у водяній системі є ступінь гідрофільності, було визначено кути змочування вибраних гідрофобізуючих добавок на різних поверхнях.

На гладку поверхню металевої пластини, звичайного скла, а також парафінованого скла наносили ПАР 3 однаковою концентрацією розчину i вимірювали кут змочування. За допомогою WEB камери проектували бокове зображення краплі на екран i за допомогою програми AmСар знімали фото краплі, а потім у програмі AutoCAD через точку дотику трьох фаз проводили дотичну до контуру краплі.

Дослідження проводилися в лабораторних умовах на установці, показаної на рис. 1. У даній установці використовувалась WEB камера 3 десятикратним збільшенням i ціною поділки 0,05 мм.

У таблиці подано результати дослідження крайового кута змочування поверхні, дані змочування поверхні гідрофобізованого гіпсу об’ємною та поверхневою гідрофобізацією при концентрації добавок $1 \%$ маси в'яжучого та коефіцієнт розм'якшення гіпсу.

Аналіз отриманих результатів свідчить про те, що найбільш ефективним з розглянутих гідрофобізаторів є добавка ГКЖ-11К, оскільки крайовий кут змочування на кожній із поверхонь (металева пластина, звичайне скло, а також парафіноване скло) мінімальний відносно інших гідрофобізаторів.

Кут між краплею води та поверхнею гідрофобізованого добавкою ГКЖ-11К гіпсу максимальний i складає при об'ємній гідрофобізації $96^{0}$, що свідчить про незмочування поверхні. Інші добавки мають менший кут, отже вони менш ефективні.

Введення до складу гіпсу Г-5 гідрофобізуючої добавки дозволяє підвищити коефіцієнт розм'якшення 3 0,4 (контрольний склад) до 0,51 , а на гіпсі марки $Г$-10 коефіцієнт розм'якшення підвищується з 0,36 до 0,48 .

Вивчено вплив гідрофобізуючої добавки ГКЖ-11К на коефіцієнт розм'якшення гіпсу на в'яжучому марки $Г-10$, для визначення оптимальної концентрації. Результати показані на рис. 2. 


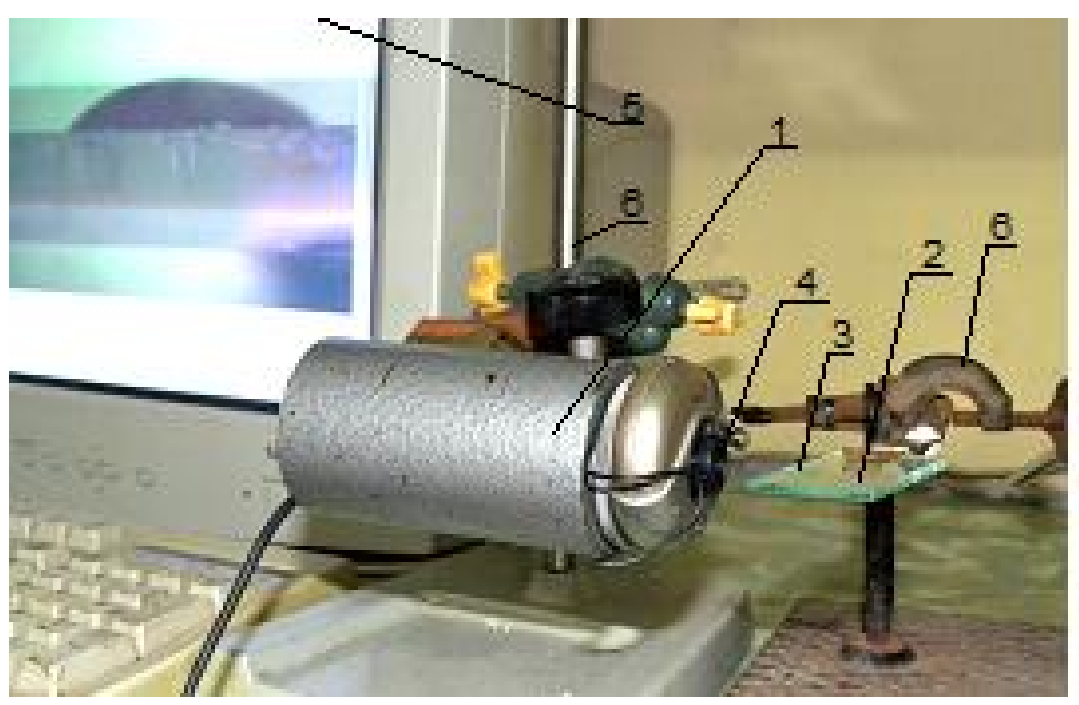

Рис. 1. Схема установки для вимірювання крайового кута:

1 - WEB камера; 2 - змочувана поверхня (скло); 3 - крапля водного розчину з добавкою;

4 - фокус камери; 5 - зображення, що виводиться на екрані; 6 - штатив

Вплив гідрофобізуючих добавок на водостійкість гіпсу

\begin{tabular}{|c|c|c|c|c|c|c|}
\hline \multicolumn{7}{|c|}{ Визначення крайового кута змочування поверхні } \\
\hline & \multicolumn{6}{|c|}{ Гідрофобізатори } \\
\hline & $\begin{array}{c}\text { ГКЖ- } \\
11 K\end{array}$ & $\begin{array}{l}\text { CR- } \\
349\end{array}$ & KO-A & $\begin{array}{l}\text { Water Reppelent } \\
\text { Aquasil WO }\end{array}$ & $\begin{array}{c}\text { Гідроізолятор МC- } \\
\text { Вauchemie }\end{array}$ & $\begin{array}{l}\text { Master } \\
\text { Gidro }\end{array}$ \\
\hline \multicolumn{7}{|c|}{ Металева поверхня } \\
\hline $\begin{array}{c}\text { Кут } \\
\text { змочування }\end{array}$ & 28 & 35 & 36 & 37 & 51 & 53 \\
\hline \multicolumn{7}{|c|}{ Скло } \\
\hline $\begin{array}{c}\text { Кут } \\
\text { змочування }\end{array}$ & 27 & 33 & 42 & 52 & 59 & 87 \\
\hline \multicolumn{7}{|c|}{ Парафінове скло } \\
\hline $\begin{array}{c}\text { Кут } \\
\text { 3мочування }\end{array}$ & 25 & 28 & 37 & 47 & 54 & 60 \\
\hline \multicolumn{7}{|c|}{ Змочування поверхні гідрофобізованого гіпсу } \\
\hline \multicolumn{7}{|c|}{ Об’ємна гідрофобізація } \\
\hline $\begin{array}{c}\text { Кут } \\
\text { змочування }\end{array}$ & 96 & 96 & 80 & 71 & 55 & 48 \\
\hline t погл., с & $\begin{array}{c}\text { не } \\
\text { погл. }\end{array}$ & $\begin{array}{c}\text { не } \\
\text { погл. }\end{array}$ & не погл & 6 & $6-7$ & $19-20$ \\
\hline \multicolumn{7}{|c|}{ Поверхнева гідрофобізація } \\
\hline $\begin{array}{c}\text { Кут } \\
\text { 3мочування }\end{array}$ & 91 & 87 & 78 & 63 & 57 & 50 \\
\hline t погл., с & $\begin{array}{c}\text { не } \\
\text { погл. }\end{array}$ & $\begin{array}{c}\text { не } \\
\text { погл. }\end{array}$ & 128 & $17-18$ & $23-24$ & 50 \\
\hline Вид в'яжучого & \multicolumn{6}{|c|}{ Коефіцієнт розм'якшення, Кр } \\
\hline $\begin{array}{c}\Gamma-5 \\
\kappa p=0,4\end{array}$ & 0,51 & 0,49 & 0,48 & 0,42 & 0,41 & 0,4 \\
\hline $\begin{array}{c}\Gamma-10 \\
\mathrm{Kp}=0,36\end{array}$ & 0,48 & 0,45 & 0,44 & 0,4 & 0,39 & 0,38 \\
\hline
\end{tabular}




\section{Будівельні матеріали, конструкції та споруди}

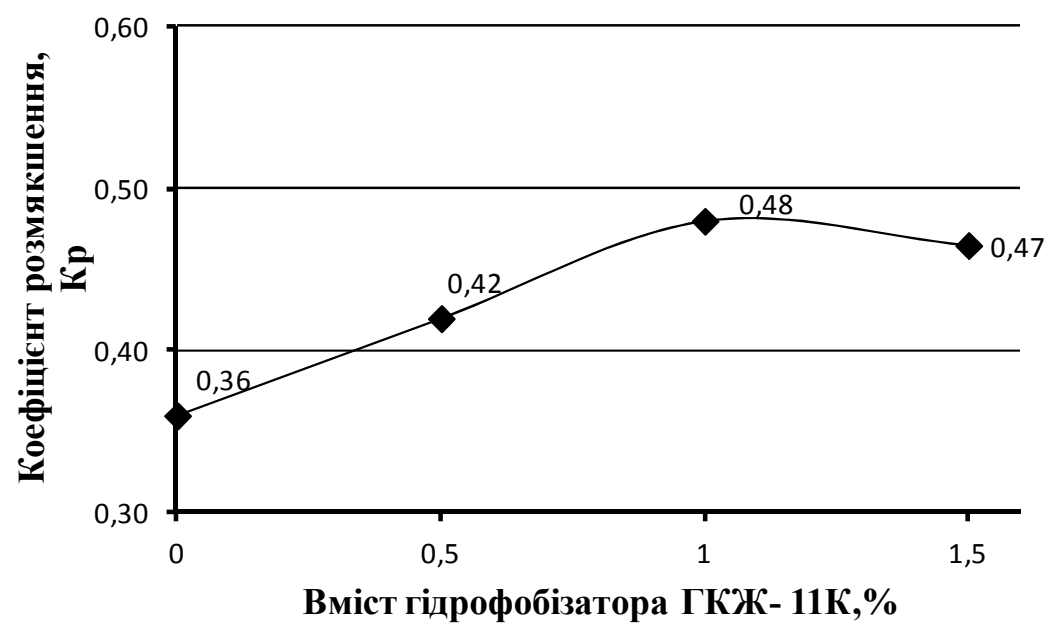

Рис. 2. Вплив гідрофобізуючої добавки ГКЖ-11К на коефіцієнт розм'якшення гіпсу

Проведеними дослідами встановлено, що зміна концентрації гідрофобізуючої добавки ГКЖ-11К від 0,5 до $1 \%$ маси в'яжучого сприяє підвищенню коефіцієнта розм'якшення Кр, подальше збільшення концентрації до 1,5\% призводить до незначного зниження коефіцієнта розм'якшення.
Висновки 3 дослідження і перспективи, подальший розвиток у даному напрямку. Результати досліджень дозволили вибрати найбільш ефективну гідрофобізуючу добавку, визначити оптимальну ऑii концентрацію та спосіб застосування і будуть використані в подальших дослідженнях.

\section{Список використаних джерел}

1. Коровяков, В.Ф. Гипсовые вяжущие и их применение в строительстве [Текст] / В.Ф. Коровяков // Химия современных строительных материалов. - 2003. - Вып. 4. - С.18-25.

2. Гипсовые материалы и изделия (производство и применение) [Текст] / под ред. А.В. Ферронской. - М.: АСВ, 2004. - 488 с.

3. Завадская, JI.В. Газогипс - эффективный энергосберегающий материал для современного строительства [Текст] / ЈI.В. Завадская // Третья всеросс. науч.-практ. конф.: сб. докладов. Челябинск: Южно-Уральский государственный университет, 2010. - С. 53-57.

4. Керш, В.Я. Оптимизация свойств полистиролгипсобетона [Текст] / В.Я. Керш, А.В. Фощ // Вісник ОДАБА. - Одеса: «Зовнішрекламсервіс», 2011. - Вип. 44. - С.354-361.

5. Волженский, А.В. Гипсоцементно-пуццолановые вяжущие, бетоны и изделия [Текст] / А.В. Волженский, В.И. Стамбулко, А.В. Ферронская. - М.: Стройиздат, 1971. - 318 с.

6. Волженский, А.В. Гипсоцементные и гипсошлаковые вяжущие материалы и изделия [Текст]/ А.В. Волженский, М.И. Роговой, В.И. Стамбулко. - М.: Госстройиздат, 1960. - 162 с.

7. Ферронская, А.В. Развитие теории и практики в области гипсовых вяжущих веществ [Текст] / А.В. Ферронская // Сб. «Развитие теории и технологий в области силикатных и гипсовых материалов». - М.: МГСУ, 2000. - Ч.1. - С. 47-56.

8. Михеенков, М.А. Прессование как способ повышения водостойкости гипсового вяжущего [Текст] / М.А. Михеенков // Вестник МГСУ. - 2009. - Вып. 4. - С. 158-162.

9. Коровяков, В.Ф. Перспективы применения водостойких гипсовых вяжущих в современном строительстве [Текст] / В.Ф. Коровяков // Повышение эффективности производства и применения гипсовых материалов и изделий: матер. Всеросс. семинара. - М., 2002. - С. 51-56.

10. Кондращенко, О.В. Гіпсові будівельні матеріали підвищеної міцності і водостійкості (фізико-хімічні та енергетичні основи) [Текст]: автореф. дис... д-ра техн. наук: 05.23.05 / О.В. Кондращенко. - Харків: УкрДАЗТ, 2005. - 40 с. 
11. The influences of gypsum water-proofing additive on gypsum crystal growth / J. Li, G.Li, Y. Yu // Materials Letters. - 2007. - № 61. - P. 872-876.

Рецензент д-р техн. наук, професор В.М. Вировой

Фощ Альона Вікторівна, канд. техн. наук, доцент кафедри міського будівництва та господарства Одеської державної академії будівництва та архітектури. Тел.: (097)045-62-62 E-mail: nikitkos@gmail.com.

Керш Володимир Якович, канд. техн. наук, професор кафедри міського будівництва та господарства Одеської державної академії будівництва та архітектури. Тел.: (067)775-42-04 E-mail: vkersh@hotmail.com. Колесніков Андрій Валерійович, старший викладач, Одеська державна академія будівництва та архітектури. Тел.: (050)554-84-13 E-mail: kolesn@stikonet.od.ua.

Foshch A. V., Cand. Sc., Associate Prof. Department of Urban Development and Municipal Engineering Odessa State Academy of Civil Engineering and Architecture. Tel.: (097)045-62-62 E-mail: nikitkos@gmail.com.

Kersh V.Ya., Cand. Sc., Prof. Department of Urban Development and Municipal Engineering Odessa State Academy of Civil Engineering and Architecture. Tel.: (067) 775-42-04 E-mail: vkersh@hotmail.com.

Kolesnikov A.V., Assistant Prof. Odessa State Academy of Civil Engineering and Architecture. Tel.: (050)554-84-13. E-mail: kolesn@stikonet.od.ua.

Стаття прийнята 28.10 .2015 p. 